University of Nebraska - Lincoln

DigitalCommons@University of Nebraska - Lincoln

2006

\title{
Microbial Reduction Of Fe(III) In The Fithian And Muloorina Illites: Contrasting Extents And Rates Of Bioreduction
}

\author{
Jennifer L. Seabaugh \\ Miami University \\ Hailiang Dong \\ Miami University, dongh@muohio.edu \\ Ravi K. Kukkadapu \\ Pacific Northwest National Laboratory, ravi.kukkadapu@pnl.gov \\ Dennis D. Eberl \\ United States Geological Survey \\ John P. Morton \\ Miami University \\ See next page for additional authors
}

Follow this and additional works at: https://digitalcommons.unl.edu/usdoepub

Part of the Bioresource and Agricultural Engineering Commons

Seabaugh, Jennifer L.; Dong, Hailiang; Kukkadapu, Ravi K.; Eberl, Dennis D.; Morton, John P.; and Kim, Jinwook, "Microbial Reduction Of Fe(III) In The Fithian And Muloorina Illites: Contrasting Extents And Rates Of Bioreduction" (2006). US Department of Energy Publications. 142.

https://digitalcommons.unl.edu/usdoepub/142

This Article is brought to you for free and open access by the U.S. Department of Energy at DigitalCommons@University of Nebraska - Lincoln. It has been accepted for inclusion in US Department of Energy Publications by an authorized administrator of DigitalCommons@University of Nebraska - Lincoln. 
Authors

Jennifer L. Seabaugh, Hailiang Dong, Ravi K. Kukkadapu, Dennis D. Eberl, John P. Morton, and Jinwook Kim 


\title{
MICROBIAL REDUCTION OF Fe(III) IN THE FITHIAN AND MULOORINA ILLITES: CONTRASTING EXTENTS AND RATES OF BIOREDUCTION
}

\author{
Jennifer L. Seabaugh ${ }^{1}$, Hailiang Dong ${ }^{1}{ }^{*}$, Ravi K. Kukkadapu ${ }^{2}$, Dennis D. Eberl ${ }^{3}$, John P. Morton ${ }^{1}$ \\ AND JINWOOK KIM ${ }^{4}$ \\ ${ }^{1}$ Department of Geology, Miami University, Oxford, OH 45056, USA \\ ${ }^{2}$ Pacific Northwest National Laboratory, Richland, WA 99352, USA \\ ${ }^{3}$ United States Geological Survey, Boulder, CO 80303, USA \\ ${ }^{4}$ Naval Research Laboratory, Seafloor Sciences Branch, Stennis Space Center, MS 39529, USA
}

\begin{abstract}
Shewanella putrefaciens CN32 reduces Fe(III) within two illites which have different properties: the Fithian bulk fraction and the $<0.2 \mu \mathrm{m}$ fraction of Muloorina. The Fithian illite contained $4.6 \%(\mathrm{w} / \mathrm{w})$ total $\mathrm{Fe}, 81 \%$ of which was Fe(III). It was dominated by illite with some jarosite $(\sim 32 \%$ of the total $\mathrm{Fe}(\mathrm{III}))$ and goethite $(11 \%$ of the total $\mathrm{Fe}(\mathrm{III}))$. The Muloorina illite was pure and contained $9.2 \% \mathrm{Fe}$, $93 \%$ of which was Fe(III). Illite suspensions were buffered at $\mathrm{pH} 7$ and were inoculated with $\mathrm{CN} 32$ cells with lactate as the electron donor. Select treatments included anthraquinone-2,6-disulfonate (AQDS) as an electron shuttle. Bioproduction of $\mathrm{Fe}(\mathrm{II})$ was determined by ferrozine analysis. The unreduced and bioreduced solids were characterized by Mössbauer spectroscopy, X-ray diffraction and transmission electron microscopy. The extent of Fe(III) reduction in the bulk Fithian illite was enhanced by the presence of AQDS (73\%) with complete reduction of jarosite and goethite and partial reduction of illite. Mössbauer spectroscopy and chemical extraction determined that $21-25 \%$ of illite-associated Fe(III) was bioreduced. The extent of bioreduction was less in the absence of AQDS (63\%) and only jarosite was completely reduced with partial reduction of goethite and illite. The XRD and TEM data revealed no significant illite dissolution or biogenic minerals, suggesting that illite was reduced in the solid state and biogenic Fe(II) from jarosite and goethite was either released to aqueous solution or adsorbed onto residual solid surfaces. In contrast, only $1 \%$ of the structural $\mathrm{Fe}(\mathrm{III})$ in Muloorina illite was bioreduced. The difference in the extent and rate of bioreduction between the two illites was probably due to the difference in layer charge and the total structural Fe content between the Fithian illite (0.56 per formula) and Muloorina illite (0.87). There may be other factors contributing to the observed differences, such as expandability, surface area and the arrangements of $\mathrm{Fe}$ in the octahedral sheets. The results of this study have important implications for predicting microbe-induced physical and chemical changes of clay minerals in soils and sediments.
\end{abstract}

Key Words - CN32, Fithian, Illite, Microbial Fe(III) Reduction, Mössbauer Spectroscopy, Muloorina, Shewanella putrefaciens.

\section{INTRODUCTION}

Iron, one of the most redox active metals in the Earth's crust, is often bound as a structural component of Fe oxide and silicate minerals. Studies have shown that subsurface microorganisms can couple the oxidation of various organic substrates to the reduction of ferric $\mathrm{Fe}$ contained in Fe oxides and silicates (Dong et al., 2000; Fredrickson et al., 1998; Kostka et al., 1999a, 1999b; Lovely, 2000; Nealson and Little, 1997; Roden and Zachara, 1996). The result of this microbial action can affect the integrity of the Fe-bearing minerals and increase $\mathrm{Fe}$ bioavailability. Microbial reduction of $\mathrm{Fe}$ in oxides and silicates may contribute to the release of phosphates and trace metals adsorbed to these soil components (Zachara et al. 2001).

Several studies have shown that Fe-reducing bacteria are capable of reducing structural $\mathrm{Fe}$ in smectite, a

* E-mail address of corresponding author: dongh@muohio.edu

DOI: $10.1346 / \mathrm{CCMN} .2006 .0540109$ dominant clay mineral in soils and shallow sediments (Stucki et al., 1987; Kostka et al., 1996, 1999a, 1999b; Dong et al., 2003; Kim et al., 2004). When smectite is buried and subjected to increased temperature and pressure, it transforms to other types of clays, of which illite is the most abundant (Hower et al., 1976; Dong and Peacor, 1996; Dong et al., 1997). Illite is an Fe-bearing mineral that usually possesses Fe concentrations in the range of $<1$ to $>8 \mathrm{wt} . \%$ (Norrish and Pickering, 1983). Illite is not only abundant in sub-surface environments but is also ubiquitous in soils, sediments and sedimentary rocks. Additionally, it can possess a large surface area and cation exchange capacity (Fanning et al., 1989). Due to these characteristics, illite can play an important role in environmental processes including nutrient cycling, organic matter maturation, petroleum migration and contaminant migration. The rate and extent to which these processes occur are a function of the physical and chemical properties of illite which are influenced by the oxidation state of $\mathrm{Fe}$ in the structure.

Although illite is one of the most abundant Fe(III)bearing clay minerals in the subsurface environment, 
microbial interaction with illite minerals has not been studied extensively. Dong et al. (2003) first studied microbial reduction of $\mathrm{Fe}(\mathrm{III})$ in illite, finding that Fe(III) associated with a well ordered illite was accessible to Fe-reducing bacteria in the presence of the electron shuttle, anthraquinone-2,6-disulfonate (AQDS). The present study expands the work of Dong et al. (2003) in testing the hypothesis that the extent and rate of bioreduction of $\mathrm{Fe}(\mathrm{III})$ in the illite structure is largely controlled by physical and chemical properties of illite, especially layer charge and the total Fe(III) content.

The goal of this study was to assess the factors influencing the rate and extent of microbial reduction of $\mathrm{Fe}(\mathrm{III})$ in two different illite minerals. Shewanella putrefaciens $\mathrm{CN} 32$, an Fe-reducing facultative anaerobe isolated from the Morrison Formation in New Mexico, was used in the experiments. Chemical extraction methods, X-ray diffraction (XRD), and Mössbauer spectroscopy were used to monitor and quantify $\mathrm{Fe}(\mathrm{II})$ production and to characterize the structural distribution of $\mathrm{Fe}(\mathrm{II})$ and $\mathrm{Fe}$ (III) in both the starting and bioreduced illite samples. Results from this study show that Fe(III) in the illite structure can be accessible to microbes. Furthermore, we find that the rate and extent of bioreduction depends on the total layer charge and the total structural Fe content. These findings have important implications for contaminated surface and subsurface environments, where Fe(III)-bearing clay minerals may be predominant and may be the major electron acceptor available to microorganisms.

\section{MATERIALS AND METHODS}

\section{Microbe, minerals and media}

Shewanella putrefaciens strain CN32 was provided by Dr David Boone (Portland State University, Portland, Oregon). Strain CN32 was isolated from a $250 \mathrm{~m}$ subsurface core sample from the Morrison Formation in northwestern New Mexico. Cells were cultured aerobically in tryptic soy broth (TSB), $30 \mathrm{~g} / \mathrm{L}$ (Difco Laboratories, Detroit, Michigan), and stock cultures were maintained by freezing in $35 \%$ glycerol at $-80^{\circ} \mathrm{C}$.

Muloorina separates and bulk Fithian illite were used in reduction experiments. These two illite samples differ in the total Fe(III) content and layer charge in the structure (see below). The Muloorina illite sample was kindly provided by Will Gates, CSIRO Land and Water, Australia. It is found in the Billa Kalina Clay Member of the Etadunna Formation, occurring as a soft green clay layer up to $6 \mathrm{~m}$ thick. It is lacustrine in origin and Oligocene in age (Norrish and Pickering, 1983). The $<0.2 \mu \mathrm{m}$ size fraction was separated from the bulk material by repeated gravity settling and centrifugation. The bulk Fithian illite was purchased from Wards National Science Est. Inc. and used for the bioreduction experiments. Both samples were characterized by chemi- cal and spectroscopy methods to determine the total $\mathrm{Fe}$ content and $\mathrm{Fe}(\mathrm{II}) / \mathrm{Fe}(\mathrm{III})$ ratio. Additionally, XRD was used to determine the mineralogy of the starting illite materials. Mössbauer spectroscopy was used to determine the structural nature of Fe present in the clays. The illite samples described above will be referred to hereafter as the starting material.

A defined solution was used for the bioreduction studies. Solution components for the bioreduction experiments included $\mathrm{Fe}(\mathrm{III})$ in the illite starting materials as the sole electron acceptor, lactate (Sigma Chemical Co., St. Louis, Missouri, USA) as the sole electron donor, and CN32 cells harvested in log phase as mediator. The solutions were buffered with bicarbonate buffer with a measured $\mathrm{pH}$ of $\sim 7$. The buffer was prepared with $2.5 \mathrm{~g} / \mathrm{L}$ reagent-grade $\mathrm{NaHCO}_{3}$ and $0.1 \mathrm{~g} / \mathrm{L} \mathrm{KCl}$. In selected replicates, the humic acid analog anthraquinone-2,6-disulfonate (AQDS) (Sigma Chemical Co.) was added as an electron shuttle. In order to ensure a resting cell study, there were no additional nutrients added to the buffer.

\section{Bacterial reduction experiments}

Each illite starting material was suspended in bicarbonate buffer to yield clay stock solutions $\left(100 \mathrm{mg}\right.$ of clay/mL) which were autoclaved at $121^{\circ} \mathrm{C}$ under a pressure of $21 \mathrm{psi}$ for $20 \mathrm{~min}$. Stock solutions of $10 \mathrm{mM}$ AQDS and $1 \mathrm{M}$ sodium lactate were filter sterilized $(0.2 \mu \mathrm{m})$. The bicarbonate buffer was autoclaved. Components of each treatment were combined in $25 \mathrm{~mL}$ capacity glass culture tubes to a final volume of $20 \mathrm{~mL}$, included in which was $2 \mathrm{~mL}$ of clay stock slurry (final concentration, $10 \mathrm{mg} / \mathrm{mL}$ ), $400 \mu \mathrm{L}$ of $1 \mathrm{M}$ sodium lactate, $200 \mu \mathrm{L}$ of $10 \mathrm{mM}$ AQDS (in selected tubes), and $2 \mathrm{~mL}$ log-phase $\mathrm{CN} 32$ cells $\left(\sim 8 \times 10^{6}\right.$ cells $/ \mathrm{mL}$, final concentration) pre-washed three times with sterilized bicarbonate buffer. These components were brought to $20 \mathrm{~mL}$ final volume with sterilized bicarbonate buffer. All component transfers were made with sterile syringes under strictly anaerobic atmosphere. Control tubes did not include CN32 cells but received $2 \mathrm{~mL}$ sterile bicarbonate buffer instead. Each treatment was prepared in triplicate and purged for $15 \mathrm{~min}$ with $\mathrm{O}_{2}$-free $\mathrm{N}_{2} / \mathrm{CO}_{2}$ (80:20) gas mixture. The headspace was purged for $5 \mathrm{~min}$ before the tubes were stopped with thick butyl rubber stoppers and crimp sealed. The tubes were incubated at $30^{\circ} \mathrm{C}$ and shaken at $70 \mathrm{rpm}$. The Fithian illite experiment was allowed to incubate for 17 days while the Muloorina illite experiment ran for 25 days.

\section{Analyses}

Each illite starting material was analyzed for total $\mathrm{Fe}$ content. The total $\mathrm{Fe}$ in the samples was determined by mixing each with $\mathrm{LiBO}_{2}$ flux, fusing the mix at $950^{\circ} \mathrm{F}$ in a graphite furnace for $20 \mathrm{~min}$, suspending the fused mixture in $5 \% \mathrm{HNO}_{3}(\mathrm{v} / \mathrm{v})$, and then analyzing via direct 
current plasma (DCP) spectroscopy. To estimate the relative proportion of poorly crystalline Fe oxides in the illites, the starting materials were extracted with acidic ammonium oxalate (AAO) (Phillips and Lovely, 1987). The ammonium oxalate-extracted solids were analyzed by Mössbauer spectroscopy. The ammonium oxalate extractant was analyzed for Fe concentration by DCP.

A citrate-bicarbonate-dithionite (CBD) procedure (Jackson et al., 1986) was used to extract crystalline Fe oxides in the Fithian starting material. The material was extracted with the CBD solution (anoxic $0.3 \mathrm{M} \mathrm{Na}$ citrate, $1 \mathrm{~mL}$ of $1 \mathrm{M}$ anaerobic bicarbonate, and $200 \mathrm{mg}$ of $\mathrm{Na}$ dithionite) overnight in a $30^{\circ} \mathrm{C}$ incubator with shaking $(25 \mathrm{rpm})$. This was repeated, and the residual solid was washed three times in anoxic $0.1 \mathrm{M}$ sodium perchlorate solution and once in anaerobic $30 \mathrm{mM}$ bicarbonate solution. The CBD-extracted solid was prepared for Mössbauer spectroscopy. The extractant was analyzed for Fe, K, Si and Al concentration by DCP spectroscopy.

The extent of microbial reduction in both illite samples was monitored by measuring the increase in $\mathrm{Fe}$ (II) concentration over time. At select time points, $0.2 \mathrm{~mL}$ of the cell-mineral suspensions were sampled with a sterile syringe and added to $2.0 \mathrm{~mL}$ capacity plastic micro-centrifuge tubes containing $0.2 \mathrm{~mL}$ of $1.0 \mathrm{~N} \mathrm{HCl}$. This mixture was allowed to stand for $24 \mathrm{~h}$ and then centrifuged at $30,000 \mathrm{rpm}$ for $10 \mathrm{~min}$ and $0.1 \mathrm{~mL}$ of the acidified supernatant solution was added to $1.0 \mathrm{~mL}$ of Ferrozine for spectrophotometer analysis at $562 \mathrm{~nm}$. Spectrophotometer readings were interpreted on a standard curve for the concentration of $\mathrm{Fe}(\mathrm{II})$. This extraction was termed the $0.5 \mathrm{~N} \mathrm{HCl}$ extraction and has been shown to be effective for extracting microbially produced $\mathrm{Fe}(\mathrm{II})$ in adsorbed form and $\mathrm{Fe}(\mathrm{II})$ in biogenic solids such as siderite, with the exception of highly crystalline magnetite (Fredrickson et al., 1998; Zachara et al., 1998). However, this method may not extract $\mathrm{Fe}(\mathrm{II})$ associated with silicates. Our laboratory has compared the extraction efficiency by $0.5 \mathrm{~N} \mathrm{HCl}$ and $\mathrm{HF}$, and our results have shown that the amount of $\mathrm{Fe}(\mathrm{II})$ in bioreduced nontronite as measured by HF dissolution is approximately $10-15 \%$ greater than that measured by the $0.5 \mathrm{~N} \mathrm{HCl}$ extraction (Jaisi et al., pers. comm.). The $0.5 \mathrm{~N} \mathrm{HCl}$ extraction does not release any $\mathrm{Si}, \mathrm{Al}$ and $\mathrm{K}$, suggesting that this extraction does not measure $\mathrm{Fe}(\mathrm{II})$ associated with silicates. Thus, the $0.5 \mathrm{~N} \mathrm{HCl}$ extraction method may slightly underestimate the extent of bioreduction.

Concentrations of major elements not adsorbed onto solids (i.e. aqueous ions) were determined by DCP at the selected time points. One $\mathrm{mL}$ of clay-bacterial suspension was sampled from tubes with a sterile syringe and filtered through a Whatman PVDF $0.2 \mu \mathrm{m}$ syringe filter. The filtrate was collected in plastic tubes containing $1 \mathrm{~mL}$ of $1.0 \mathrm{~N} \mathrm{HCl}$. This acid mixture was prepared and analyzed for aqueous $\mathrm{Fe}, \mathrm{Mg}, \mathrm{Al}$ and $\mathrm{Si}$ concentrations.

\section{$X$-ray diffraction (XRD)}

The starting materials were analyzed by XRD. Powder XRD patterns were obtained with a Phillips PW3040/00 X'Pert MPD system, using $\mathrm{CuK} \alpha$ radiation with a variable divergent slit and a solid-state detector. The routine power was $700 \mathrm{~W}(35 \mathrm{kV}, 20 \mathrm{~mA})$. Low background quartz XRD slides (Gem Dugout, Inc., Pittsburg, Pennsylvania) were used. For analysis, powder samples were tightly packed into the well of the slides (0.6 cm diameter). Crystal thickness distribution was determined using polyvinylpyrrolidone (PVP) treatment (Eberl et al., 1998).

\section{Mössbauer spectroscopy}

${ }^{57} \mathrm{Fe}$ transmission Mössbauer spectroscopy was employed to characterize the Fe mineralogy of the starting materials and the nature of the bioreduced minerals. Mössbauer spectroscopy is a very sensitive and Fespecific technique. For the unreduced Fithian illite material, room temperature (RT), $77 \mathrm{~K}, 12 \mathrm{~K}$ Mössbauer spectra were obtained. The $77 \mathrm{~K}$ and $12 \mathrm{~K}$ Mössbauer spectra were obtained for the bioreduced material at the final time points of both the Muloorina and Fithian illite experiments (25 and 17 days, respectively). Details of the sample preparation, the instrumentation, data collection, calibration, and folding of the data have been described elsewhere (Fredrickson et al., 2001; Kukkadapu et al., 2001). For measurements at liquid nitrogen and $12 \mathrm{~K}$ temperatures, only the absorber was at this temperature, and both the source and drive assemblies were still at room temperature. All Mössbauer spectra were fitted with quadrupole splitting distributions (QSDs) or hyperfine field distributions (HFDs), using the Voigt-based fitting method (Rancourt and Ping, 1991). This method is commonly used to estimate the relative proportions of $\mathrm{Fe}$ in various minerals (van der Zee et al., 2003).

\section{Transmission and analytical electron microscopy}

High-resolution imaging and chemical analyses were performed using a Philips CM12 scanning transmission electron microscope (STEM) fitted with a Kevex Quantum solid-state detector and computer system at the University of Michigan. The STEM was operated at $120 \mathrm{kV}$ and a beam current of $20 \mu \mathrm{A}$. A camera length of $770 \mathrm{~nm}$ and a selected area aperture $10 \mu \mathrm{m}$ in diameter were used to obtain selected area electron diffraction (SAED) patterns. Quantitative energy dispersive spectrum (EDS) chemical analyses were obtained in scanning mode by using a beam diameter of $50 \AA$ and a scanning area of $300 \times 300 \AA$. Standards and other conditions used were similar to those defined previously (Dong and Peacor, 1996). The mineral particles mounted on $\mathrm{Cu}$ grids were observed using the Philips CM12 STEM for morphology, electron diffraction, and chemical analyses.

The crystal morphology of the control and bioreduced material was compared at the end of the experiment for signs of biogenic activity. Material was prepared by a 


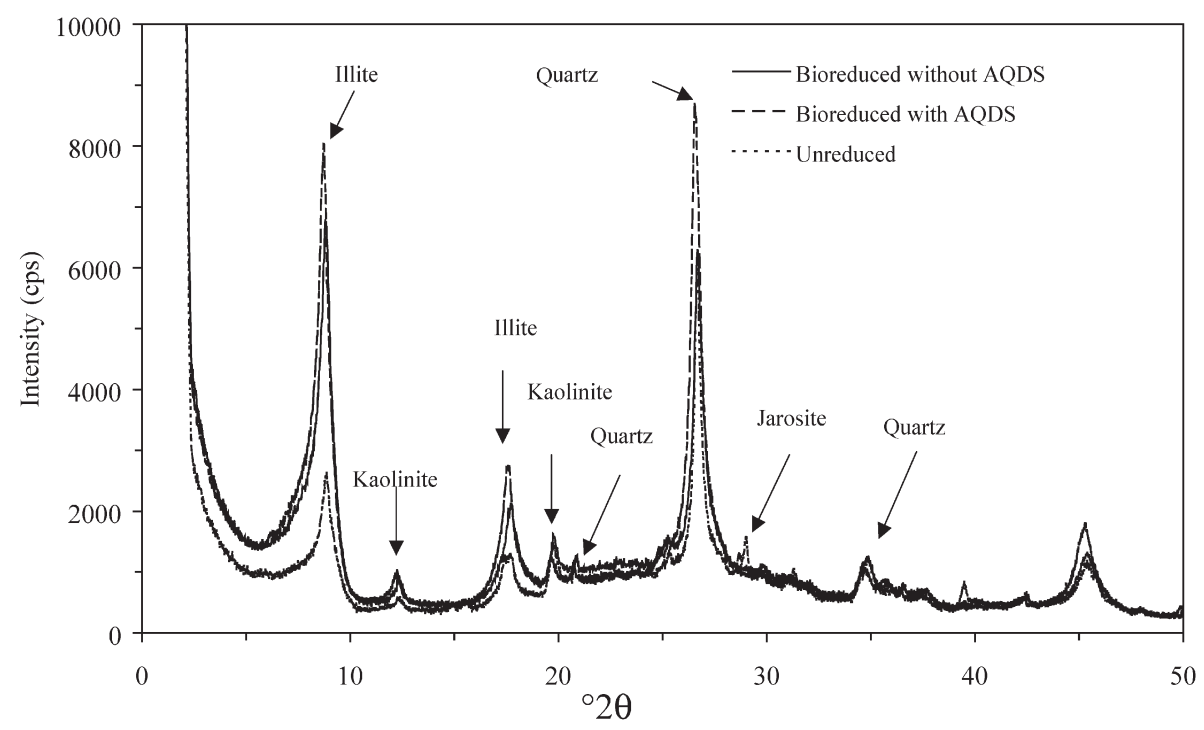

Figure 1. XRD pattern of the ethylene glycolated Fithian illite material before and after bioreduction. Three traces, from the top, are bioreduced with AQDS, bioreduced without AQDS, and the unreduced (original) Fithian material. Jarosite was only present in the unreduced material. It was removed as a result of bioreduction.

graded ethanol series and a Spurr's firm resin infiltration series. The resin was hardened at $65^{\circ} \mathrm{C}$ for $72 \mathrm{~h}$ and sectioned with a diamond knife on a Reichert Ultracut to obtain ultrathin sections. Sections were placed on 300 mesh $\mathrm{Cu}$ grids, viewed on a JOEL 100S TEM and photographed at $100 \mathrm{kV}$.

\section{Surface area analysis of illites}

The external surface area of each dry illite sample, the bulk Fithian and $<0.2 \mu \mathrm{m}$ Muloorina illites, was determined using a Coulter SA3100 surface area analyzer. The samples were prepared by drying and outgassing at $40^{\circ} \mathrm{C}$ for $60 \mathrm{~min}$. A multipoint $\mathrm{N}_{2}$-BET isotherm was performed in the analysis.

\section{RESULTS}

\section{Characteristics of the illite starting materials}

Fithian illite. The Fithian illite contained $4.6 \%(\mathrm{w} / \mathrm{w})$ total $\mathrm{Fe}$ (or $0.84 \mathrm{mmol} \mathrm{Fe} / \mathrm{g}$ sample) as determined by DCP spectroscopy, $81 \%$ of which was $\mathrm{Fe}(\mathrm{III})$ as determined by Mössbauer spectroscopy. X-ray diffraction revealed that a small amount of jarosite $\left\{\mathrm{KFe}_{3}\left(\mathrm{SO}_{4}\right)_{2}\left(\mathrm{OH}_{6}\right) ; \sim 6 \%\right\}$ was admixed with the illite (Figure 1). The TEM imaging showed that the illite crystals were discrete with respect to each other (Figure 2). Quantitative EDS analyses determined the formula of illite as $\left(\mathrm{Na}_{0.11} \mathrm{~K}_{0.86} \mathrm{Ca}_{0.07}\right)$ $\left(\mathrm{Fe}_{0.67} \mathrm{Mg}_{0.47} \mathrm{Al}_{2.87}\right)\left(\mathrm{Al}_{1.05} \mathrm{Si}_{6.95}\right)(\mathrm{OH})_{4} \mathrm{O}_{20}$; a layer charge of 0.56 per $11 \mathrm{O}$. Polyvinylpyrrolidone intercalation indicated an asymptotic crystallite thickness distribution, with a mean thickness of $5.3 \mathrm{~nm}$. The surface area of the Fithian material was $85 \mathrm{~m}^{2} / \mathrm{g}$.

Variable-temperature Mössbauer spectroscopy was further used to characterize the $\mathrm{Fe}$ mineralogy of the
Fithian clay (Figure 3). The room temperature (RT) Mössbauer spectrum showed two doublets representing $\mathrm{Fe}(\mathrm{III})$ associated with (1) jarosite and (2) illite and $\mathrm{Fe}$ oxides (ferrihydrite and small-particle goethite; see below), and one doublet representing Fe(II) in illite (Figure 3a). Ferrihydrite, small-particle goethite and illite $\mathrm{Fe}(\mathrm{III})$ all exhibit a doublet (i.e. central doublet) at room temperature (RT) with similar parameters, making it difficult to resolve their contributions from each other at this temperature. Fortunately, smallparticle goethite, unlike ferrihydrite and illite Fe(III), displays a sextet at lower temperatures, due to the superparamagnetism effect (Greenwood and Gibb, 1971). A sextet with Mössbauer parameters typical of small-particle goethite (Murad and Cashion, 2005) was evident at $77 \mathrm{~K}$ (Figure 3b). The RT and $77 \mathrm{~K}$ Mössbauer parameters of jarosite agreed well with the literature values (Herbert, 1997). A magnetically ordered

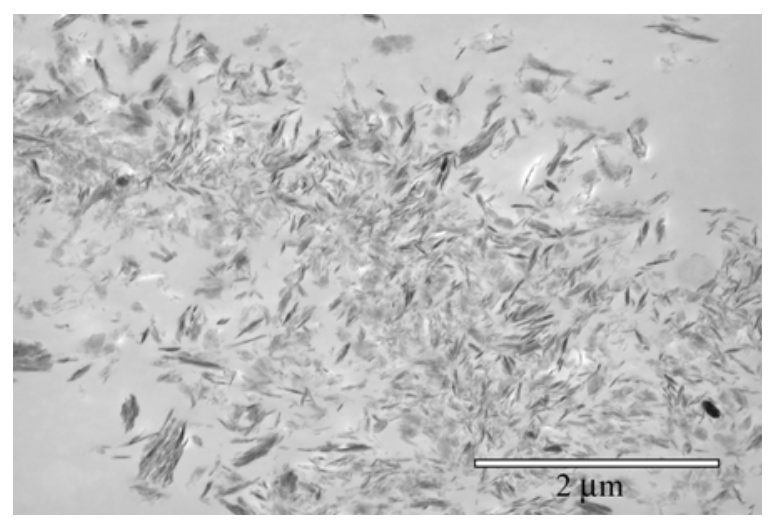

Figure 2. TEM image showing dispersed illite particles in the unreduced Fithian illite sample. 


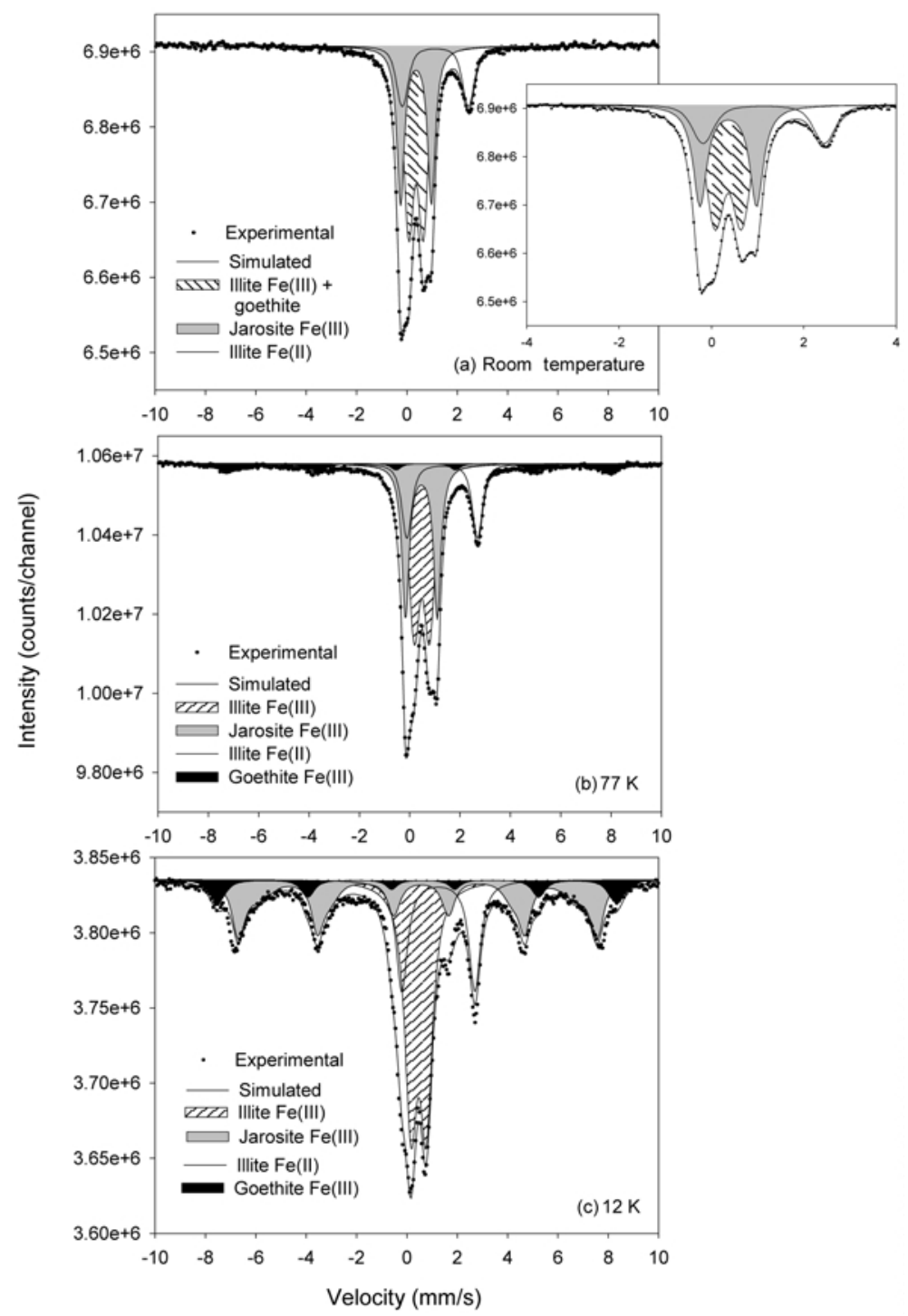

Figure 3. Mössbauer spectra of the Fithian illite starting material at: (a) room temperature (RT) showing the relative percentage of Fe associated with illite and jarosite; (b) $77 \mathrm{~K}$ revealing Fe(III) associated with goethite and jarosite; and (c) $12 \mathrm{~K}$ showing jarosite, goethite and illite. The inset in Figure 3 a shows an enlargement from -4 to $4 \mathrm{~mm} / \mathrm{s}$ velocity.

jarosite was evident at $12 \mathrm{~K}$ (Figure 3c). Jarosite magnetically orders below liquid-nitrogen temperature (Taneja and Jones, 1984). The minor sextet (outer) in this spectrum was due to small-particle goethite. The distribution of $\mathrm{Fe}$ among various phases was similar at $77 \mathrm{~K}$ and $12 \mathrm{~K}$ (Table 1 ).

The DCP analysis of the acid ammonium oxalate extractant revealed that there was a small contribution of Fe from the poorly crystalline Fe phases in the starting Fithian material $(6.3 \%$ of the total $\mathrm{Fe}$ in the sample). Comparison of the $77 \mathrm{~K}$ Mössbauer spectra for the unreduced Fithian illite material to that of the AAO extracted, unreduced material (Figures $3 \mathrm{~b}$ and $4 \mathrm{a}$, respectively) showed a relatively small change in Fe distribution in the minerals after the AAO treatment. The $77 \mathrm{~K}$ Mössbauer spectrum (AAO-treated sample) revealed $\mathrm{Fe}$ distribution among various minerals (excluding ferrihydrite). In the AAO-treated sample, the relative percent of various minerals was: $\mathrm{Fe}(\mathrm{III})$ associated with goethite $(6 \%), \mathrm{Fe}(\mathrm{III})$ associated with jarosite $(36 \%), \mathrm{Fe}(\mathrm{III})$ associated with illite $(39 \%)$, and $\mathrm{Fe}(\mathrm{II})$ associated with illite $(19 \%)$. The $\mathrm{Fe}(\mathrm{II}) / \mathrm{Fe}(\mathrm{III})$ ratio of illite in the AAO treated sample was 0.48 (Figure 4a).

The starting Fithian material was treated with CBD to remove any reducible $\mathrm{Fe}$ oxides from the sample. The DCP analysis of aqueous Fe in the CBD extractant showed that $1.35 \%(w / w) \mathrm{Fe}(29 \%$ of total $\mathrm{Fe}$ in the sample) was extracted from the starting material. The $12 \mathrm{~K}$ spectrum of the unreduced material (Figure 3c) revealed that the Fe present in goethite constituted $\sim 9 \%$ of the total $\mathrm{Fe}$ in the sample but Fe from goethite did not account for all of the Fe present in the CBD extractant. 
Table 1. Fit-derived Mössbauer parameters (CS, QS, e and $\left.B_{\mathrm{hf}}\right)^{1}$ of the Fithian illite experiments.

\begin{tabular}{|c|c|c|c|c|c|c|}
\hline Sample & Temp. & Fe species & $\begin{array}{l}<\mathrm{CS}>^{2} \\
(\mathrm{~mm} / \mathrm{s})\end{array}$ & $\begin{array}{c}<\mathrm{QS}>\text { or }<\mathrm{e}> \\
(\mathrm{mm} / \mathrm{s})\end{array}$ & $\begin{array}{c}<B_{\mathrm{hf}}> \\
\text { (Tesla) }\end{array}$ & Spectral area \\
\hline \multirow[t]{11}{*}{ Unreduced } & \multirow[t]{3}{*}{ RT } & Silicate $\mathrm{Fe}(\mathrm{III})^{3}$ & 0.367 & 0.578 & - & $47.2(11)$ \\
\hline & & Jarosite Fe(III) & 0.367 & 1.226 & - & $34.4(12)$ \\
\hline & & Silicate $\mathrm{Fe}(\mathrm{II})$ & 1.133 & 2.628 & - & $18.35(52)$ \\
\hline & \multirow[t]{4}{*}{$77 \mathrm{~K}$} & Silicate $\mathrm{Fe}(\mathrm{III})^{4}$ & 0.486 & 0.598 & - & $42.12(96)$ \\
\hline & & Jarosite Fe(III) & 0.467 & 1.257 & - & $30.21(100)$ \\
\hline & & Silicate $\mathrm{Fe}(\mathrm{II})$ & 1.293 & 2.799 & - & $18.39(40)$ \\
\hline & & Goethite & 0.511 & -0.13 & 46.37 & $9.27(66)$ \\
\hline & \multirow[t]{4}{*}{$12 \mathrm{~K}$} & Silicate $\mathrm{Fe}(\mathrm{III})^{4}$ & 0.471 & 0.607 & - & $39.4(43)$ \\
\hline & & Jarosite $\mathrm{Fe}(\mathrm{III})$ & 0.501 & -0.069 & 42.08 & $32.63(54)$ \\
\hline & & Silicate Fe(II) & 1.251 & 2.9 & - & $18.49(35)$ \\
\hline & & Goethite & 0.527 & -0.124 & 49.08 & $9.48(9)$ \\
\hline \multirow[t]{4}{*}{ Unreduced + AAO } & \multirow[t]{4}{*}{$77 \mathrm{~K}$} & Silicate Fe(III) & 0.476 & 0.592 & - & $39.2(14)$ \\
\hline & & Jarosite $\mathrm{Fe}(\mathrm{III})$ & 0.475 & 1.253 & - & $36.0(14)$ \\
\hline & & Silicate Fe(II) & 1.267 & 2.856 & - & $19.16(65)$ \\
\hline & & Goethite & 0.431 & -0.09 & 47.32 & $5.66(81)$ \\
\hline \multirow[t]{2}{*}{ Unreduced + CBD } & \multirow[t]{2}{*}{$12 \mathrm{~K}$} & Silicate Fe(III) & 0.46 & 0.65 & - & $59.83(32)$ \\
\hline & & Silicate Fe(II) & 1.248 & 2.922 & - & $40.17(32)$ \\
\hline \multirow[t]{2}{*}{ Bioreduced (AQDS) } & \multirow[t]{2}{*}{$77 \mathrm{~K}$} & Silicate Fe(III) & 0.465 & 0.576 & - & $40.58(39)$ \\
\hline & & $\begin{array}{l}\text { Silicate } \mathrm{Fe}(\mathrm{II})+ \\
\text { Biogenic } \mathrm{Fe}(\mathrm{II})\end{array}$ & 1.259 & 2.922 & - & $59.42(39)$ \\
\hline \multirow[t]{2}{*}{ Bioreduced (AQDS) $(+\mathrm{HCl})$} & \multirow[t]{2}{*}{$77 \mathrm{~K}$} & Silicate Fe(III) & 0.462 & 0.573 & - & $64.14(74)$ \\
\hline & & Silicate $\mathrm{Fe}(\mathrm{II})^{5}$ & 1.243 & 2.931 & - & $35.86(74)$ \\
\hline \multirow[t]{2}{*}{ Bioreduced (AQDS) } & \multirow[t]{2}{*}{$12 \mathrm{~K}$} & Silicate Fe(III) & 0.465 & 0.578 & - & $40.85(22)$ \\
\hline & & $\begin{array}{l}\text { Silicate } \mathrm{Fe}(\mathrm{II})+ \\
\text { Biogenic } \mathrm{Fe}(\mathrm{II})\end{array}$ & 1.262 & 2.914 & - & $59.15(22)$ \\
\hline \multirow[t]{3}{*}{ Bioreduced (w/o AQDS) } & \multirow[t]{3}{*}{$12 \mathrm{~K}$} & Silicate Fe(III) & 0.465 & 0.637 & - & $46.40(53)$ \\
\hline & & $\begin{array}{l}\text { Silicate Fe(II) + } \\
\text { Biogenic Fe(II) }\end{array}$ & 1.253 & 2.904 & - & $45.58(53)$ \\
\hline & & Goethite & 0.465 & -0.147 & 47.487 & $8.02(79)$ \\
\hline
\end{tabular}

${ }^{1}<\mathrm{CS}>=$ center shift; $<\mathrm{QS}>=$ average quadrupole shift; $<\mathrm{e}>=$ average quadrupole shift parameter, and $B_{\mathrm{hf}}=$ average hyperfine field.

${ }_{2}^{2}$ with respect to metallic $20 \mu \mathrm{m}$ Fe foil at RT

3 a contribution from AAO-extractable $\mathrm{Fe}+$ a small particle of goethite

4 a contribution from AAO-extractable Fe

5 assuming $0.5 \mathrm{~N} \mathrm{HCl}$ extracted all of the biogenic $\mathrm{Fe}(\mathrm{II})$

Thus, we concluded that some Fe from other phases was also extracted by CBD. Mössbauer spectroscopy of the CBD-treated solid (Figure $4 \mathrm{~b}$ ) revealed that all Fe associated with both goethite and jarosite had been removed. A comparison of the $12 \mathrm{~K}$ Mössbauer spectra for the untreated and $\mathrm{CBD}$-treated materials revealed that the silicate $\mathrm{Fe}(\mathrm{II}) / \mathrm{Fe}(\mathrm{III})$ ratio also increased from 0.47 to 0.67 . This represents a substantial increase in the amount of $\mathrm{Fe}(\mathrm{II})$ as a result of $\mathrm{CBD}$ extraction.

Muloorina illite. Muloorina illite contained 9.2\% Fe (w/w), 93\% of which was $\mathrm{Fe}(\mathrm{III})$ as determined by Mössbauer spectroscopy (Figure 5). X-ray diffraction indicated that this was a relatively pure illite with no other detectable Fe-bearing minerals (data not shown), in agreement with the $77 \mathrm{~K}$ Mössbauer spectrum (Figure 5). Quantitative EDS analyses determined the following formula for illite: $\left(\mathrm{Na}_{0.44} \mathrm{~K}_{1.29}\right)$ $\left(\mathrm{Fe}_{1.22} \mathrm{Mg}_{0.82} \mathrm{Al}_{1.96}\right)\left(\mathrm{Al}_{0.73} \mathrm{Si}_{7.27}\right)(\mathrm{OH})_{4} \mathrm{O}_{20}$. The total layer charge was 0.87 per $11 \mathrm{O}$. The DCP analysis of ammonium oxalate extractant and comparison of Mössbauer spectra for the untreated and AAO-treated samples revealed that the $\mathrm{X}$-ray amorphous $\mathrm{Fe}$ oxide contribution to the total $\mathrm{Fe}$ in the Muloorina illite sample was negligible $(<1 \%)$. The BET surface area of the starting material was $107 \mathrm{~m}^{2} / \mathrm{g}$. 


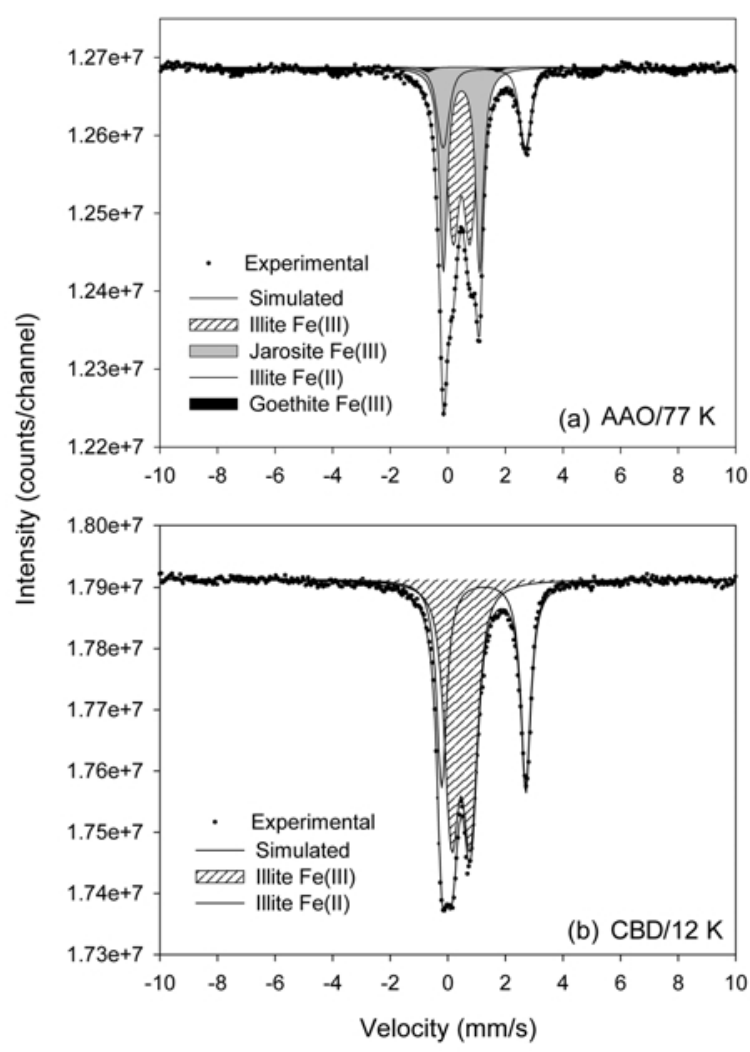

Figure 4. Mössbauer spectra of the Fithian starting material chemically treated with: (a) acid ammonium oxalate (AAO) showing little effect on the Fe mineralogy and the contribution of X-ray amorphous Fe; and (b) citrate-bicarbonate-dithionite (CBD) showing the removal of Fe associated with goethite and jarosite.

\section{Microbial reduction of illite samples}

Fithian illite experiments. The presence of AQDS $(0.1 \mathrm{mM})$ stimulated the extent of $\mathrm{Fe}(\mathrm{III})$ bioreduction. This was evidenced by the higher concentration of $\mathrm{HCl}$-extractable $\mathrm{Fe}(\mathrm{II})$ in the AQDS treatment over that for the treatment without AQDS (Figure 6a). In addition to the extent of reduction, the rate at which Fe(III) was reduced was also greater in the AQDS treatment than in its absence, with the majority of the bioreduction taking place within $48 \mathrm{~h}$. Maximum reduction for both treatments (with and without AQDS) took place quickly, within 10 days. With reference to the $\mathrm{Fe}$ (III) concentration in the starting material and with the notion that the increase in $0.5 \mathrm{~N} \mathrm{HCl}$-extractable $\mathrm{Fe}(\mathrm{II})$ was due to $\mathrm{Fe}(\mathrm{III})$ bioreduction, the extent of bioreduction was $73 \%$ in the presence of AQDS. In the absence of AQDS, $63 \%$ of the total $\mathrm{Fe}$ (III) was reduced. Neither control, with or without AQDS, showed any significant reduction. Aqueous concentration of $\mathrm{Fe}$ comprised a significant portion of the total biogenic Fe(II) (i.e. $0.5 \mathrm{~N}$ HCl-extractable $\mathrm{Fe}(\mathrm{II})$ ); $\sim 43 \%$ with $\mathrm{AQDS}$ and $~ 53 \%$ without AQDS. The aqueous $\mathrm{Fe}$ concentration in the controls was minimal (Figure 6b). Unless otherwise stated, 'the bioreduced solid' would refer only to the residue in the experimental treatment with AQDS.

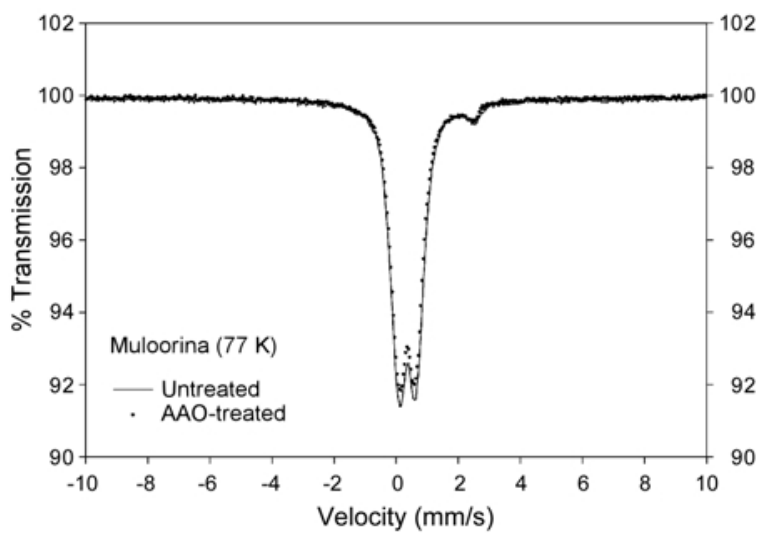

Figure 5. Mössbauer spectra of the Muloorina illite at $77 \mathrm{~K}$ showing pure illite. The AAO-treated sample showed no difference.

None of the XRD, DCP or TEM results showed any evidence of illite dissolution as a result of the bioreduction. The XRD patterns did not show any diminishing illite peaks after bioreduction (Figure 1), but showed the disappearance of jarosite. The DCP analysis of aqueous $\mathrm{Al}, \mathrm{Si}$ and $\mathrm{Mg}$ on the first and last time-point of the experiment showed insignificant increases in the concentrations of these elements (data not shown), implying no reductive dissolution. Our TEM observations support these data. Illite crystals showed no noticeable morphological changes as a result of bioreduction. Crystal-size distribution remained the same as well (asymptotic crystallite thickness distribution, with a mean thickness of $5.3 \mathrm{~nm}$ ). However, while the illite crystals of the control were dispersed (Figure 2), flocculation of the illite crystals was noticed in the bioreduced material (Figure 7).

Mössbauer spectroscopy was employed to determine the change of $\mathrm{Fe}$ mineralogy as a result of bioreduction. For example, a comparison between the $12 \mathrm{~K}$ Mössbauer spectra of the unreduced (Figure 3c) and the bioreduced samples (Figure 8a) indicated significant differences. Most notably, the two sextets representing Fe(III) in jarosite and goethite disappeared, suggesting complete reduction of Fe(III) in both minerals. Another significant change was an increase in the Fe(II) spectral area. The fit-derived $\mathrm{Fe}(\mathrm{II})$ content increased from $20 \%$ for the unreduced sample to $60 \%$ for the bioreduced sample. This increase in $\mathrm{Fe}(\mathrm{II})$, at face value, appeared to suggest complete bioreduction of $\mathrm{Fe}$ (III) in goethite and jarosite to $\mathrm{Fe}(\mathrm{II})$ with little or no reduction of illite-associated $\mathrm{Fe}(\mathrm{III})$. This observation was consistent with the absence of $\mathrm{Si}, \mathrm{Al}$ and $\mathrm{Mg}$ in aqueous solution. However, the presence of a significant amount of aqueous Fe(II) (Figure 6b) indicated otherwise. In other words, the increase in $\mathrm{Fe}(\mathrm{II})$ signal was not entirely due to bioreduction of goethite and jarosite. Fe(III) associated with illite was partly reduced as well.

Because the side doublet representing Fe(II) could contain $\mathrm{Fe}(\mathrm{II})$ in both structural and adsorbed forms, in 

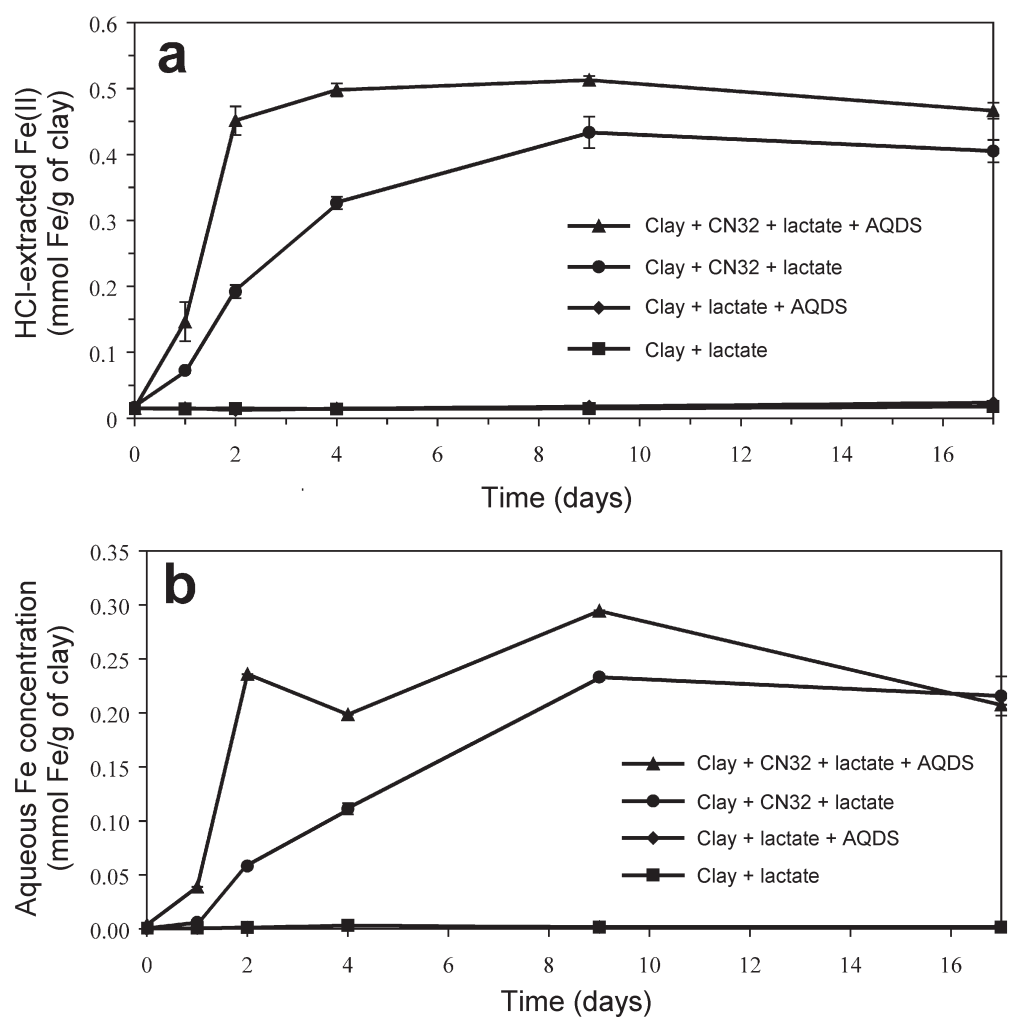

Figure 6. Change in $0.5 \mathrm{~N} \mathrm{HCl}$-extractable Fe(II) (a) and aqueous Fe(II) concentration (b) in the Fithian illite experiment with time. The concentrations of Fe(II) are expressed in mmol per gram of the bulk Fithian clay (including illite, goethite, jarosite and a minor amount of amorphous Fe oxides). The addition of AQDS enhanced the extent and rate of microbial Fe(III) reduction of the starting material.

order to determine the extent of $\mathrm{Fe}(\mathrm{III})$ bioreduction in the illite structure accurately, any surface-adsorbed Fe would have to be removed. This was achieved by $0.5 \mathrm{~N}$ $\mathrm{HCl}$ extraction. The resulting Mössbauer spectrum showed only pure illite, after the bioreduction and $\mathrm{HCl}$ extraction (Figure $8 \mathrm{~b}$ ). The $\mathrm{Fe}(\mathrm{II}) / \mathrm{Fe}(\mathrm{III})$ ratio in illite

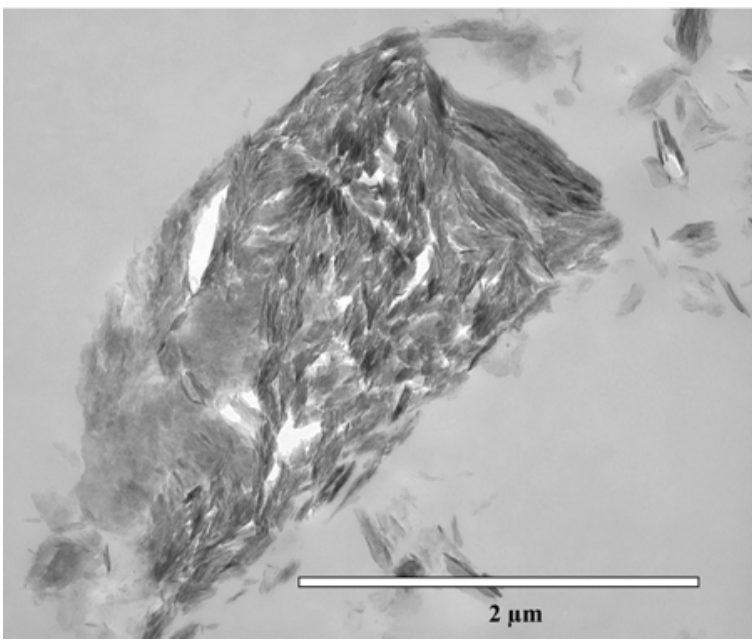

Figure 7. TEM image showing aggregated nature of the Fithian illite particles as a result of bioreduction. increased from 0.48 in the unreduced sample to 0.56 in the bioreduced sample, suggesting partial reduction of $\mathrm{Fe}(\mathrm{III})$ in the illite structure.

The increase in the $\mathrm{Fe}(\mathrm{II}) / \mathrm{Fe}$ (III) ratio from 0.48 to 0.56 represented only $4 \%$ of reduction of $\mathrm{Fe}$ (III) within the illite structure. However, the total extent of bioreduction for illite was actually greater because some biogenic $\mathrm{Fe}$ (II) from the reduction of $\mathrm{Fe}$ (III) in illite was released into solution. Specifically, the sum of the $\mathrm{Fe}$ from jarosite $(32.6 \%$ of the total Fe by weight in the bulk or $0.27 \mathrm{mmol} / \mathrm{g}$ sample based on the unreduced Mössbauer spectrum) and goethite $(9.5 \%$ or $0.08 \mathrm{mmol} / \mathrm{g}$ sample) that were completely removed by the bioreduction, did not account for the amount of $0.5 \mathrm{~N} \mathrm{HCl}$ extractable $\mathrm{Fe}$ (II) $(0.47 \mathrm{mmol} \mathrm{Fe} / \mathrm{g}$ sample) minus the amount of $\mathrm{Fe}(\mathrm{III})$ associated with ferrihydrite $(0.05$ $\mathrm{mmol} / \mathrm{g}$ as it was extracted by AAO). Because a negligible amount of $\mathrm{Fe}$ in the starting Fithian material was extracted by $0.5 \mathrm{~N} \mathrm{HCl}$, this difference $(0.47-0.27-0.08-0.05=0.07 \mathrm{mmol}$ of $\mathrm{Fe} / \mathrm{g}$ of sample $)$ would have to be due to microbial reduction of $\mathrm{Fe}(\mathrm{III})$ in illite. Microbial reduction of $\mathrm{Fe}$ (III) to $\mathrm{Fe}(\mathrm{II})$ in illite made this amount of $\mathrm{Fe}$ available for the $0.5 \mathrm{~N} \mathrm{HCl}$ extraction. This amount represented $21 \%(0.07 \mathrm{mmol}$ of $\mathrm{Fe} / \mathrm{g}$ of sample/Fe(III) in the illite structure $(0.33 \mathrm{mmol}$ $\mathrm{Fe} / \mathrm{g}$ sample)) of $\mathrm{Fe}(\mathrm{III})$ associated with illite. The total 

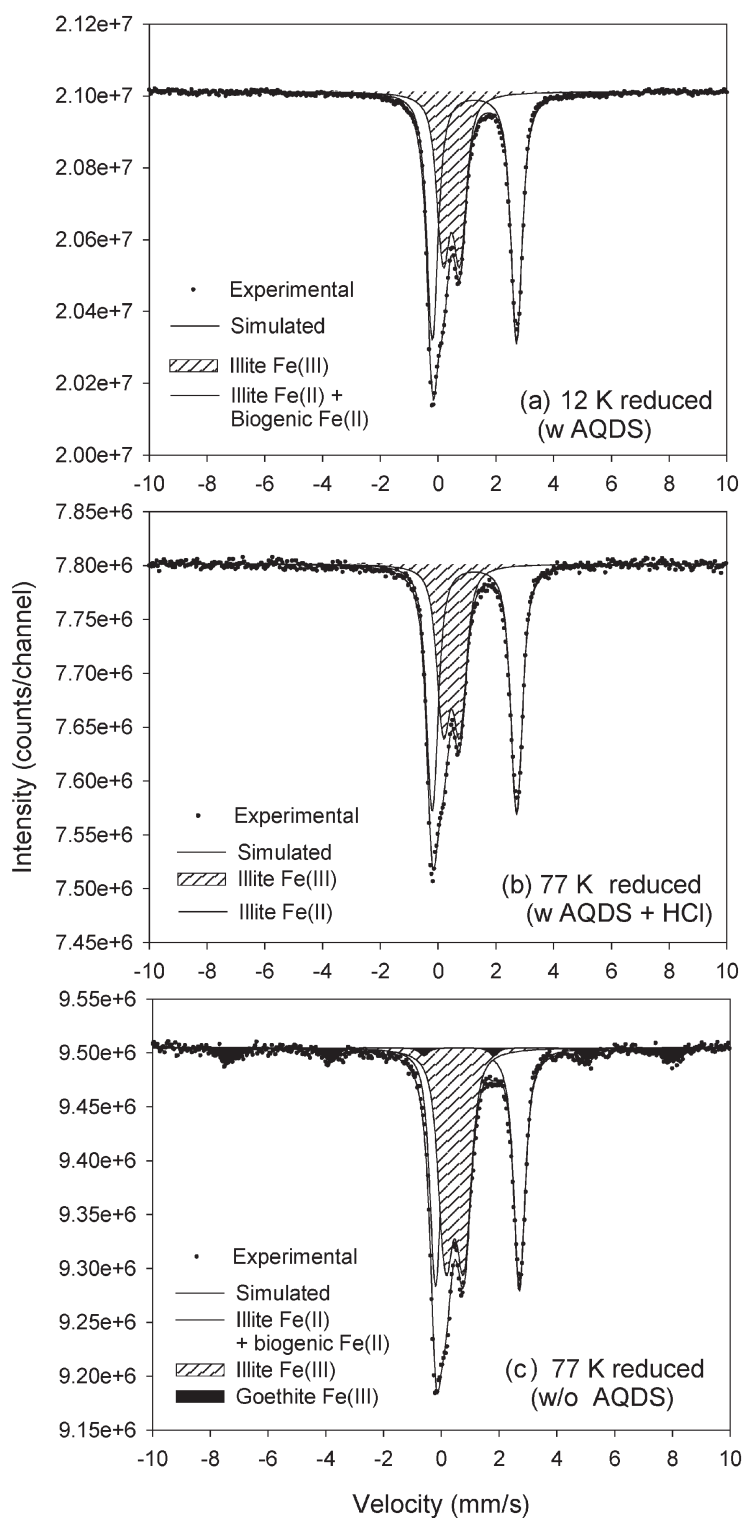

Figure 8. Mössbauer spectra of the bioreduced Fithian material. (a) A $12 \mathrm{~K}$ spectrum of the bioreduced sample with AQDS. (b) A $77 \mathrm{~K}$ spectrum of the $0.5 \mathrm{~N} \mathrm{HCl}$ extracted, bioreduced sample from the AQDS treatment. This shows an increase in the Fe(III)/ $\mathrm{Fe}$ (II) ratio in the illite structure from the unreduced sample (from 0.48 to 0.56 ). (c) A $77 \mathrm{~K}$ spectrum of solids from the experimental treatment without AQDS showing that goethite remained after the bioreduction.

extent of Fe(III) bioreduction in illite was $25 \%$ (percent increase of $\mathrm{Fe}(\mathrm{II})$ in the solid $(4 \%)+$ percent increase in aqueous $(21 \%)$ ). If the original amount of $\mathrm{Fe}(\mathrm{II})$ in the unreduced illite was proportionally released, the original amount of $\mathrm{Fe}(\mathrm{II})$ present in the illite structure had to be subtracted and the resulting extent of $\mathrm{Fe}(\mathrm{III})$ reduction in illite was $21 \%(17 \%+4 \%)$.

Comparatively, the experiment without AQDS resulted in $\sim 14-18 \%$ reduction in $\mathrm{Fe}(\mathrm{III})$ in the structure of illite. Notably, by the end of the bioreduction experiment, a sizeable proportion of the Fe associated with goethite remained in the solids (Figure 8c).

Muloorina illite experiment. The extent of $\mathrm{Fe}(\mathrm{III})$ reduction in the pure Muloorina illite (Figure 9) was vastly less than that found in the Fithian illite material. Unlike the Fithian illite, the experimental treatment without AQDS showed slightly more Fe(III) reduction. However, the extent of reduction over 25 days in both treatments was found to be small $(\sim 1 \%)$. The control maintained a low $\mathrm{Fe}(\mathrm{II})$ concentration throughout the experimental duration.

The $77 \mathrm{~K}$ Mössbauer spectral pattern for the bioreduced Muloorina illite material was similar to that for the starting material (Figure 10), suggesting that little reduction of $\mathrm{Fe}(\mathrm{III})$ took place in the clay structure. The central doublet representing Fe(III), and the side doublet representing $\mathrm{Fe}(\mathrm{II})$ had similar positions with similar Mössbauer parameters but the area of the Fe(II) peak was only slightly increased. Though not evident in the spectrum, this increase in the Fe(II) peak area corresponded to a proportional decrease in the bioreduced $\mathrm{Fe}(\mathrm{III})$ peak.

\section{DISCUSSION}

\section{Microbial reduction of Fithian and Muloorina illite samples}

Illite possesses a compact structure with few structural defects, with the implication that Fe(III) associated with illite is difficult to reduce by either bacteria or chemical reductants. Illitic clays also have greater layer charges than those of smectite clays (Peacor, 1992). With greater layer charge, the ability of the interlayers to expand decreases. Thus, high layer charge may affect the reduction capacity of structural $\mathrm{Fe}(\mathrm{III})$ owing to a decrease in its accessibility to bacteria and electron shuttle such as AQDS. The layer charge at which expandability is no longer possible remains a subject of debate. However, the limit to expandability is generally considered to be $\sim 0.6$ (Fanning et al., 1989).

Previous work by Dong et al. (2003) has shown that $\mathrm{Fe}(\mathrm{III})$ bioreduction in illite clay is possible in the presence of an electron shuttle such as AQDS. In this study, we found that the extent of Fe(III) reduction in illitic clay can be highly variable. The reduction of $\sim 21-25 \%$ of the $\mathrm{Fe}$ (III) associated with the Fithian illite structure is in stark contrast to the $1 \%$ reduction in the Muloorina illite. One possible explanation for this difference in the extent of $\mathrm{Fe}(\mathrm{III})$ reduction is the difference in the layer charge of the two illite samples. The Fithian illite has a layer charge of $\sim 0.56$ and the Muloorina illite has a layer charge of $\sim 0.87$. Clearly, it would be more difficult for the Muloorina illite to accommodate bacterial action and/or electron shuttle access to its structural $\mathrm{Fe}(\mathrm{III})$. Indeed, the presence of AQDS did not make a difference in the extent of 


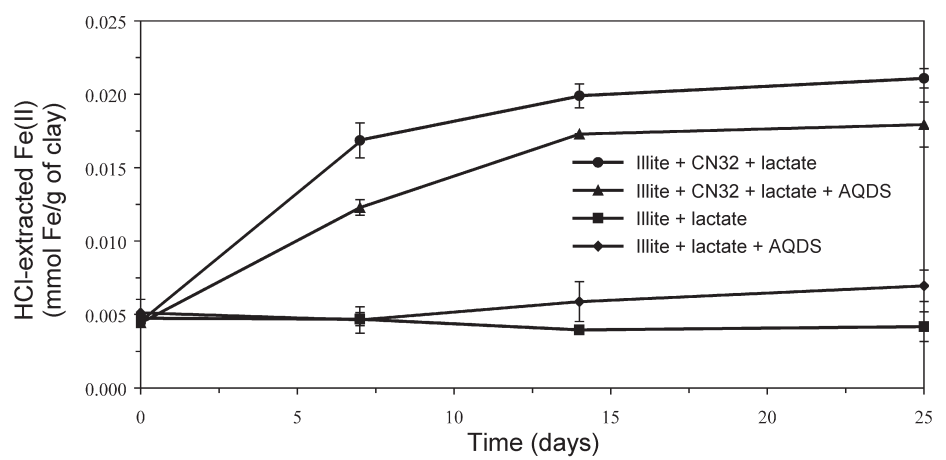

Figure 9. Ferrozine analysis of $0.5 \mathrm{~N} \mathrm{HCl}$-extractable Fe(II) in the Muloorina illite experiment. The addition of AQDS did not enhance the extent and rate of microbial Fe(III) reduction of the starting material.

bioreduction for the Muloorina illite. The chemical may have been impeded in its accessibility to Fe(III) in the illite structure, though the relationship between layer charge and AQDS effectiveness has not yet been investigated. In contrast, the Fithian illite possesses a layer charge which may allow for some expandability. The effect of AQDS was considerably larger for the Fithian illite. The AQDS may have been able to enter the expandable interlayer of the Fithian illite and to deliver electrons from lactate to $\mathrm{Fe}(\mathrm{III})$ in its structure, thus enhancing the extent of bioreduction. In the case of clays capable of full interlayer expansion (i.e. smectite), very extensive bioreduction has been observed (up to $>90 \%$, Kostka et al., 1999b). Layer expandability in clay minerals is generally correlated with the degree of crystallinity and defect density, each of which would affect how bacteria access Fe(III) in the clay structure.

Additionally, the surface area of clays often relates to the area available for environmental reactions. It is reasonable to consider this property when determining the extent to which microbes may react with clays (Roden and Zachara, 1996). In this study, however, both clays have similar surface areas, as measured by the BET

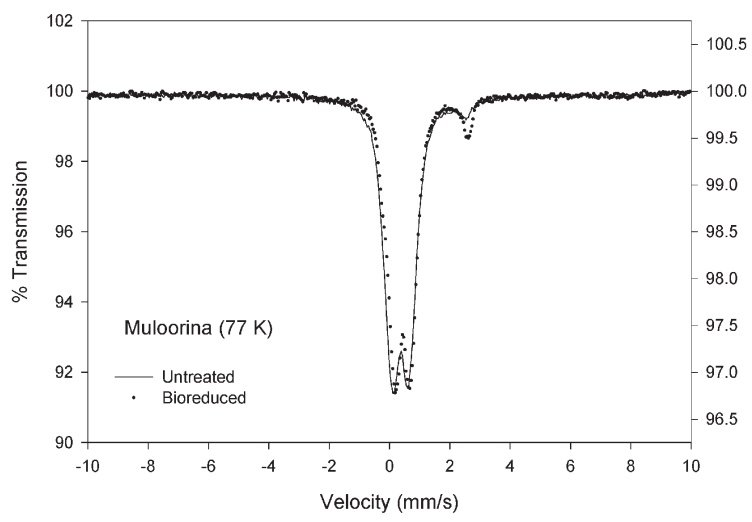

Figure 10. $77 \mathrm{~K}$ Mössbauer spectra of both the unreduced and bioreduced Muloorina materials. There was little increase in the $\mathrm{Fe}(\mathrm{II})$ peak area in the bioreduced material, indicating very little structural $\mathrm{Fe}(\mathrm{III})$ reduction by the bacteria. method, suggesting that the surface area may not be responsible for the difference in the extent and rate of bioreduction between the two illites. However, the BET method only measures external surface area, as $\mathrm{N}_{2}$ does not enter the interlayer space. The surface areas determined by particle size or by the ethylene glycol monoethyl ether method may more accurately reflect the available surface area for microbial reduction. Other complexities may be involved as well, such as particle shape and the arrangement of Fe in the octahedral sheet. Future work will focus on these additional factors in studying microbial reduction of structural $\mathrm{Fe}(\mathrm{III})$ in illite.

Relative reducibility of $\mathrm{Fe}$ (III) in Fithian illite, goethite, and jarosite

Comparison of the Muloorina and Fithian illites was complicated by the multiple Fe-bearing phases present in the Fithian illite sample. However, we have found evidence suggesting that even in the presence of other Fe-bearing phases, Fe(III) in illites may be utilized by microbes. Additionally, depending on illite properties, $\mathrm{Fe}(\mathrm{III})$ within the illite structure may even be preferentially reduced over phases whose $\mathrm{Fe}$ is considered to be more accessible to microbes. In the absence of AQDS, both jarosite- and illite-associated Fe(III) was reduced, though most $\mathrm{Fe}(\mathrm{III})$ associated with goethite was not. This preferential reduction of illite relative to goethite may be, at least in part, a function of the area of contact between bacteria and the Fe(III)-bearing minerals in the Fithian sample. In the Fithian illite material, XRD showed that illite was the dominant Fe-bearing phase, and goethite was below the detection limit. Thus, it is reasonable to assume that more $\mathrm{CN} 32$ cells were in contact with illite than with goethite in the sample. In the absence of AQDS, CN32 must reduce Fe(III) from Fe-bearing phases in close proximity, in this case, illite. However, when an electron shuttle was present, CN32 cells would have greater access to more reducible minerals. Thus, in the presence of AQDS, Fe(III) in goethite and jarosite were preferentially bioreduced. In contrast to goethite, jarosite was completely reduced 
regardless of the presence of AQDS. This may be due to the solubility effect of jarosite. Under the conditions of the experiments $(\mathrm{pH} \mathrm{7)}$, jarosite is not stable and can transform to goethite and/or X-ray amorphous Fe forms (Ettler et al., 2003).

Previous studies of microbial $\mathrm{Fe}(\mathrm{III})$ reduction have focused on pure clay minerals and few (e.g. Zachara et al. 1998 ) have considered complex natural materials. In natural soils and sediments, multiple Fe-containing minerals can co-exist (Kukkadapu et al., 2004) and their relative reducibility becomes an issue when microbe-induced changes in physical and chemical properties of bulk soils and sediments are considered. Oxides, sulfates and silicates may contribute to bulk soil and sediment properties in different ways, and $\mathrm{Fe}$ may redistribute among various minerals as a result of bioreduction. In this study, we have found evidence suggesting that the reducibility of these Fe-containing minerals may depend on geochemical conditions, such as the availability of an electron shuttle. When an electron shuttle is present, the reducibility may be determined by mineral crystallinity, particle size and surface area (Roden and Zachara, 1996). When the electron shuttle is absent, physical contact between bacterial cell and mineral surfaces may be of greater importance.

\section{Mechanism of illite reduction}

In contrast to the study by Dong et al. (2003), the results of this study do not support a reductive dissolution mechanism. Our data suggest that the illite structure may be compromised due to microbial reduction of $\mathrm{Fe}(\mathrm{III})$ to $\mathrm{Fe}(\mathrm{II})$ in the octahedral site so that that amount of $\mathrm{Fe}$ became extractable by $0.5 \mathrm{~N} \mathrm{HCl}$ but was not completely released into solution (i.e. aqueous solution). The bioreduction may have taken place in the solid state, whereas the framework of the 2:1 units of the illite structure was maintained. The solid-state bioreduction may be due to the fact that the amount of $\mathrm{Fe}(\mathrm{III})$ in the octahedral site of the Fithian illite structure was relatively small compared to that in the illite used in the Dong et al. study (2003) (i.e. 0.67 vs. 1.32 per 22 O). Because Fe(III) was only a small fraction of the cations in the octahedral site of the Fithian illite, its reduction to $\mathrm{Fe}(\mathrm{II})$ would not necessarily affect the overall structural stability. When Fe was a main cation in the octahedral site of the illite used in the Dong et al. (2003) study, its reduction to $\mathrm{Fe}(\mathrm{II})$ would have a much larger effect on the structure stability, and the structure might have broken down as a result. Indeed, when $\mathrm{Fe}(\mathrm{III})$ is a dominant cation in the smectite structure (in nontronite such as $\mathrm{SWa}-1$ ), microbial reduction of $\mathrm{Fe}$ (III) to Fe(II) in the octahedral site has been shown to cause reductive dissolution of smectite (Dong et al., 2003; O'Reilly et al., 2004). Thus, this study demonstrates that the reduction mechanism, i.e. solid state vs. dissolution, may at least in part depend on the amount of $\mathrm{Fe}$ in the structure.
Unambiguous distinction between solid-state $v s$. reductive dissolution mechanism is important for several reasons. First, if the dissolution of clays and precipitation of new clays is involved in the reduction process, all contaminants associated with the original clays will be released into solution and mobilized. This mobilization process can be beneficial or harmful depending on the particular objective. The solid-state conversion is expected to have minimal effect on the mobility of contaminants. Second, if clays are dissolved into individual components before reduction takes place, microbes have greater access to dissolved Fe(III), making efficient use of clays. Third, reduced clays formed from dissolution and precipitation would have greater probability of creating bacterial signatures than the solid-state conversion mechanism. One example of such a bio-signature is Fe isotope fractionation. These bio-signatures would have far-reaching implications in the search for life in early rock records and for life on Mars.

\section{Nature of biogenic $\mathrm{Fe}(\mathrm{II})$}

The large increase in the amount of $\mathrm{Fe}(\mathrm{II})$ in the Mössbauer spectrum for the bioreduced Fithian material indicates that much of biogenic $\mathrm{Fe}$ (II) was associated with the residual solids in addition to the large release of biogenic $\mathrm{Fe}(\mathrm{II})$ to aqueous solution. The XRD analysis did not detect the appearance of any biogenically produced mineral phases such as siderite, magnetite or green rust. Mössbauer data definitely indicated that the large amount of $\mathrm{Fe}(\mathrm{II})$ was not due to siderite (no ordering at $12 \mathrm{~K}$ ), magnetite or green rust (Kukkadapu et al., 2004). Until a thorough characterization of the biogenic Fe(II) by other methods is done, we can only speculate that this $\mathrm{Fe}(\mathrm{II})$ was adsorbed onto remaining illite particles. Indeed, a large fraction of the Fe(II) was extractable by $0.5 \mathrm{~N} \mathrm{HCl}$ (compare Figures $8 \mathrm{a}$ and $8 \mathrm{~b}$ ), consistent with this speculation. The free form and aqueous biogenic $\mathrm{Fe}(\mathrm{II})$ would be reactive to reduce other contaminant metals such as $\mathrm{U}(\mathrm{VI})$ and $\mathrm{Tc}(\mathrm{VII})$ in contaminated subsurface environments.

\section{Implications for biogeochemical transformations}

Illite can form during diagenesis in the pore spaces of sandstone thereby decreasing porosity and permeability. As such, illite is ubiquitous in sedimentary basins where, in association with smectite, it has been found to affect the migration and maturation of petroleum. Microbial activities that alter illite properties could greatly affect these processes in addition to nutrient cycling and pollutant movement in soils and sediments. In this study, we have shown that microbes can access Fe(III) in the illite structure, and that the efficiency of this process is related to illite structure and chemistry.

Historically, variables such as microbial activity, abundance, and diversity must be considered along with the geochemical considerations of shuttling compounds, 
electron donors, and electron acceptors when considering the potential biological impact on clays. However, this study suggests that layer charge may be a consideration in microbial access to clay constituents. Each of the illites in this experiment represents endmembers in layer charge within illitic clays. The Fithian illite represents an illite, the structural constituents of which may be more accessible to microbial action or chemical compounds such as humic acids. In contrast, the Muloorina illite represents an illite that demonstrates a resistance to change by biological agents. The variation in the $\mathrm{Fe}(\mathrm{III})$ reduction found in this study may thus represent a wide variation in the impact illites have on geochemical processes such as contaminant adsorption or release, nutrient cycling, and petroleum migration. Future research should consider additional factors such as particle shape, Fe(III) arrangement in the illite structure, and total surface area.

\section{CONCLUSIONS}

We found that the rate and extent of microbial reduction of structural $\mathrm{Fe}(\mathrm{III})$ bound in illite clay minerals may be controlled by the total layer charge and the total Fe(III) content of these minerals. The extent of reduction is greater and the rate faster for illite with low charge (i.e. high expandability) than illite with high charge (i.e. low expandability). When the total $\mathrm{Fe}(\mathrm{III})$ content in the octahedral site is small, a small amount of resulting biogenic Fe(II) may be able to stay in the structure without significantly affecting the stability of the overall structure. Reductive dissolution may occur when a large amount of Fe(III) is present in the structure and is microbially reduced. Furthermore, we find evidence that when multiple Fe-bearing minerals are present in natural soils and sediments, the relative order of bioreduction depends on the availability of an electron shuttle, areal contact between bacteria and the mineral to be reduced, as well as the nature of the mineral. These findings have important implications for contaminated surface and subsurface environments, where Fe(III)-bearing clay minerals may be predominant and may consist of the major electron acceptor available to microorganisms.

\section{ACKNOWLEDGMENTS}

Donors to the The Petroleum Research Fund, administered by the American Chemical Society, are acknowledged for partial support of this research. Funding was also received in the form of a grant from the National Science Foundation (EAR-0345307) to HD. The Mössbauer measurements were performed within the DOE/ OBER Environmental Molecular Sciences Laboratory user facility. Pacific Northwest National Laboratory (PNNL) is operated for the US Department of Energy by Battelle Memorial Institute under Contract DE-AC06-76RLO 1830. JWK publishes under contribution number NRL/JA/743004-10. We are grateful to two anonymous reviewers and
Associate Editor Crawford Elliott for significantly improving the quality of the manuscript.

\section{REFERENCES}

Dong, H. and Peacor, D.R. (1996) TEM observations of coherent stacking relations in smectite, I/S and illite of shales: evidence for MacEwan crystallites and dominance of $2 M_{1}$ polytypism. Clays and Clay Minerals, 44, 257-275.

Dong, H., Peacor, D.R. and Freed, R.L. (1997) Phase relations among smectite, R1 I/S and illite. American Mineralogist, 82, 379-391.

Dong, H., Fredrickson, J.K., Kennedy, D.W., Zachara, J.M., Kukkadapu, R.K. and Onstott, T.C. (2000) Mineral transformation associated with the microbial reduction of magnetite. Chemical Geology, 169, 299-318.

Dong, H., Kukkadapu, R.K., Fredrickson, J.K., Zachara, J.M., Kennedy, D.W. and Kostandarithes, H.M. (2003) Microbial reduction of structural $\mathrm{Fe}(\mathrm{III})$ in illite and goethite. Environmental Science and Technology, 37, 1268-1276.

Eberl, D.D., Drits, V.A. and Środoń, J. (1998) Deducing growth mechanisms for minerals from the shapes of crystal size distribution. American Journal of Science, 298, 449-533.

Ettler, V., Johan, Z. and Hradil, D. (2003) Natural alteration products of sulphide mattes from primary lead smelting. Comptes Rendus Geoscience, 335, 1013-1020.

Fanning, D.S., Keramidas, V.Z. and El-Desoky, M.A. (1989) Micas. Pp. 551-634 in: Minerals in Soil Environments (J.B. Dixon and S.B. Weed, editors). SSSA Book Series, Soil Science Society of America, Madison, Wisconsin.

Fredrickson, J.K., Zachara, J.M., Kennedy, D.W., Dong, H., Onstott, T.C., Hinman, N.W. and Li, S.M. (1998) Biogenic iron mineralization accompanying the dissimilatory reduction of hydrous ferric oxide by a groundwater bacterium. Geochimica et Cosmochimica Acta, 62, 3239-3257.

Fredrickson, J.K., Zachara, J.M., Kukkadapu, R.K., Gorgy, Y.A., Smith, S.C. and Brown, C.F. (2001) Biotransformation of Ni-substituted hydrous ferric oxide by an $\mathrm{Fe}(\mathrm{III})$-reducing bacterium. Environmental Science and Technology, 35, $703-712$.

Greenwood, N.N. and Gibb, T.C. (1971) Mössbauer Spectroscopy. Chapman \& Hall, London.

Hower, J., Eslinger, E.V., Hower, M.H. and Perry, E.A. (1976) Mechanism of burial metamorphism of argillaceous sediments. 1. Mineralogical and chemical evidence. Geological Society of America Bulletin, 87, 725-737.

Herbert, R.B. (1997) Properties of goethite and jarosite precipitated from acidic groundwater, Dalarna, Sweden. Clays and Clay Minerals, 45, 261-273.

Jackson, M.L., Lim, C.H. and Zelanzy, L.W. (1986) Oxides, hydroxides, and aluminosilicates. Pp. 101-150 in: Methods of Soil Analysis, Part 1. Physical and Mineralogical Methods, $2^{\text {nd }}$ edition (A. Klute, editor). American Society of Agronomy-Soil Science Society of America, Madison, Wisconsin.

Kim, J., Dong, H., Seabaugh, J. and Newell, S.W. (2004) Role of microbes in the smectite-to-illite reaction. Science, $\mathbf{3 0 3}$, $830-832$.

Kostka, J.E., Stucki, J.W., Nealson, K.H. and Wu, J. (1996) Reduction of structural $\mathrm{Fe}(\mathrm{III})$ in smectite by a pure culture of Shewanella putrefaciens strain MR-1. Clays and Clay Minerals, 44, 522-529.

Kostka, J.E., Haefele, E., Viehweger, R. and Stucki, J.W. (1999a) Respiration and dissolution of iron(III)-containing clay minerals by bacteria. Environmental Science and Technology, 33, 3127-3133.

Kostka, J.E., Wu, J., Nealson, K.H. and Stucki, J.W. (1999b) The impact of structural $\mathrm{Fe}(\mathrm{III})$ reduction by bacteria on the 
surface chemistry of smectite clay minerals. Geochimica et Cosmochimica Acta, 63, 3705-3713.

Kukkadapu, R.K., Zachara, J.M., Smith, S.C., Fredrickson, J.K. and Liu, C.X. (2001) Dissimilatory bacterial reduction of Al-substituted goethite in subsurface sediments. Geochimica Cosmochimica Acta, 65, 2913-2924.

Kukkadapu, R.K., Zachara, J.M., Fredrickson, J.K. and Kennedy, D.W. (2004) Biotransformation of two-line silica-ferrihydrite by a dissimilatory Fe(III)-reducing bacterium: formation of carbonate green rust in the presence of phosphate. Geochimica et Cosmochimica Acta, 68 , 2799-2814.

Lovely, D.R. (2000) Environmental Microbe-Metal Interactions. ASM Press, Washington, D.C.

Murad, E. and Cashion, J. (2004) Iron oxides and oxyhydroxides. Pp. 159-188 in: Mössbauer Spectroscopy of Environmental Materials and their Industrial Applications (E. Murad and J. Cashion, editors). Springer, Boston, USA

Nealson, K.H. and Little, B. (1997) Breathing manganese and iron: solid-state respiration. Advances in Applied Microbiology, 45, 213-238.

Norrish, K. and Pickering, J.G. (1983) Clay minerals. Pp. 281-308 in: Soils, an Australian Viewpoint. Division of Soils, Commonwealth Scientific and Industrial Research Organization, Australia Imprint, Melbourne - CSIRO, Academic Press, London.

O'Reilly, S.E., Bickmore, B.R. and Furukawa, Y. (2004) Dissolution of microbial reduced nontronite in a flowthrough system. Pp. 86 in: $41^{\text {st }}$ Annual Meeting of the Clay Minerals Society, Program and Abstracts.

Peacor, D.R. (1992) Diagenesis and low-grade metamorphism of shales and slates. Pp. 335-380 in: Minerals and Reactions at the Atomic Scale: Transmission Electron Microscopy (P.R. Buseck, editor). Reviews in Mineralogy,
27, Mineralogical Society of America, Washington, D.C. Phillips, E.J.P. and Lovely, D.R. (1987) Determination of $\mathrm{Fe}(\mathrm{III})$ and $\mathrm{Fe}(\mathrm{II})$ in oxalate extracts of sediments. Soil Society of America Journal, 51, 938-941.

Rancourt, D.G. and Ping, J.Y. (1991) Voigt-based method for arbitrary-shape static hyperfine parameter distributions in Mössbauer spectroscopy. Nuclear Instruments and Methods Physics Research, 41, 891-893.

Roden, E.E. and Zachara, J.M. (1996) Microbial reduction of crystalline $\mathrm{Fe}(\mathrm{III})$ oxides: Influence of oxide surface area and potential for cell growth. Environmental Science and Technology, 30, 1618-1628.

Stucki, J.W., Komadel, P. and Wilkinson, H.T. (1987) Microbial reduction of structural iron(III) in smectites. Soil Science Society of America Journal, 51, 1663-1665.

Taneja, S.P. and Jones, C.H.W, (1984) Mössbauer studies of iron-bearing minerals in coal and coal ash. Fuel, 63, $695-701$.

van der Zee, C., Roberts, D.R., Rancourt, D.G. and Slomp, C.P. (2003) Nanogoethite is the dominant reactive oxyhydroxide phase in lake and marine sediments. Geology, 31, 993-996.

Zachara, J.M., Fredrickson, J.K., Li, S.M., Kennedy, D.W., Smith, S.C. and Gassman, P.L. (1998) Bacterial reduction of crystalline $\mathrm{Fe}^{3+}$ oxides in single phase suspensions and subsurface materials. American Mineralogist, 83, $1426-1443$.

Zachara, J.M., Fredrickson, J.K., Smith, S.C. and Gassman, P.L. (2001) Solubilization of Fe(III) oxide-bound trace metals by a dissimilatory $\mathrm{Fe}(\mathrm{III})$ reducing bacterium. Geochimica et Cosmochimica Acta, 65, 75-93.

(Received 15 September 2004; revised 18 July 2005; Ms. 959; A.E. W. Crawford Elliott) 